I. Overview of Cooperation between Higher Education and Industry in Germany

Contents II. Dual System Model

III. Triple Helix Innovation

IV. Internationalization of Higher Education 


\section{Mentimeter Quiz}

Apakah profesi Anda saat ini? 


\section{Mentimeter Quiz}

Apa yang terbayangkan oleh Anda jika mendengar kata Jerman? 


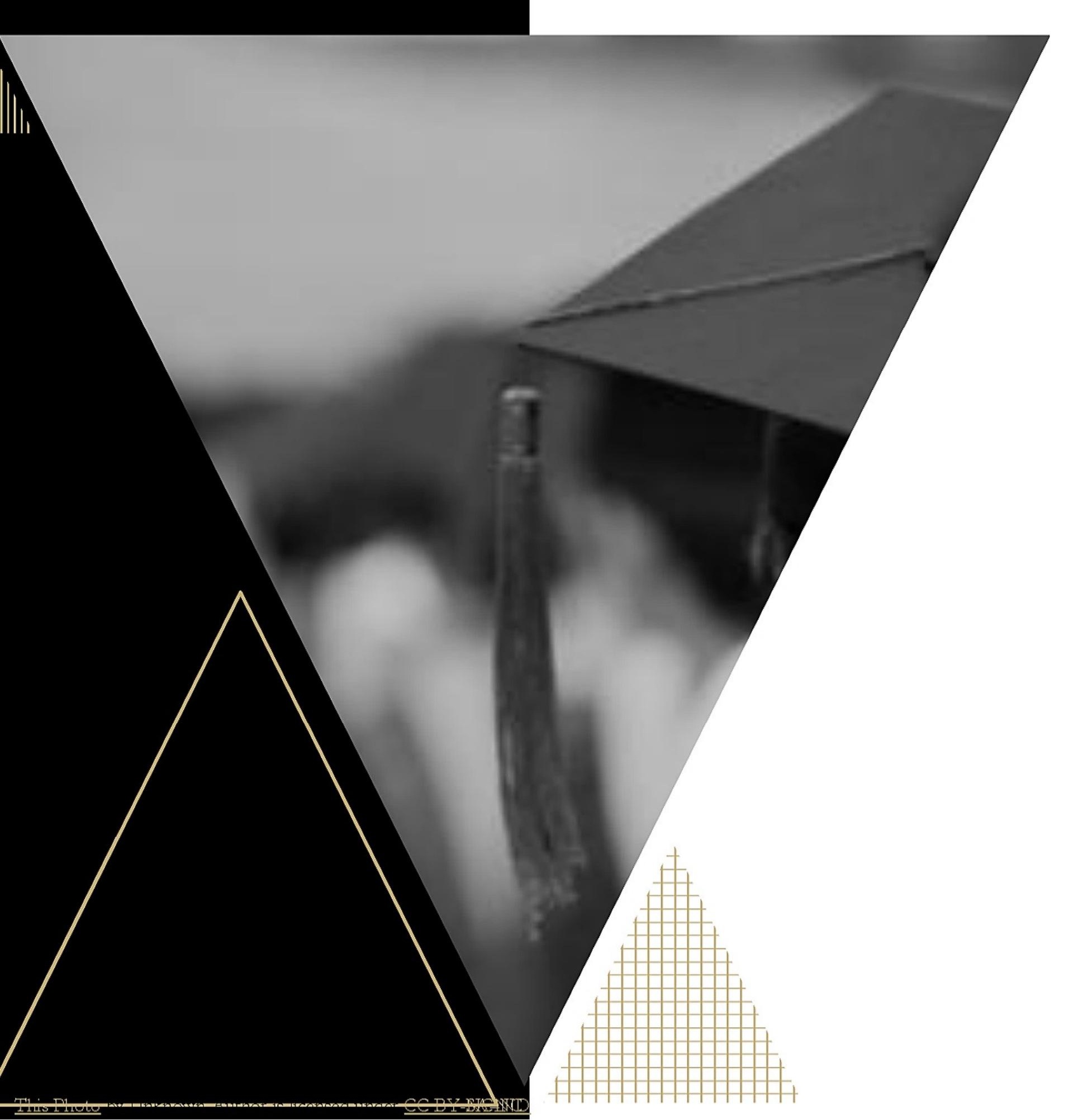

I. Cooperation between Higher Education and Industry in Germany 


\section{Industry in Germany}

World class industry,

Hidden Champions
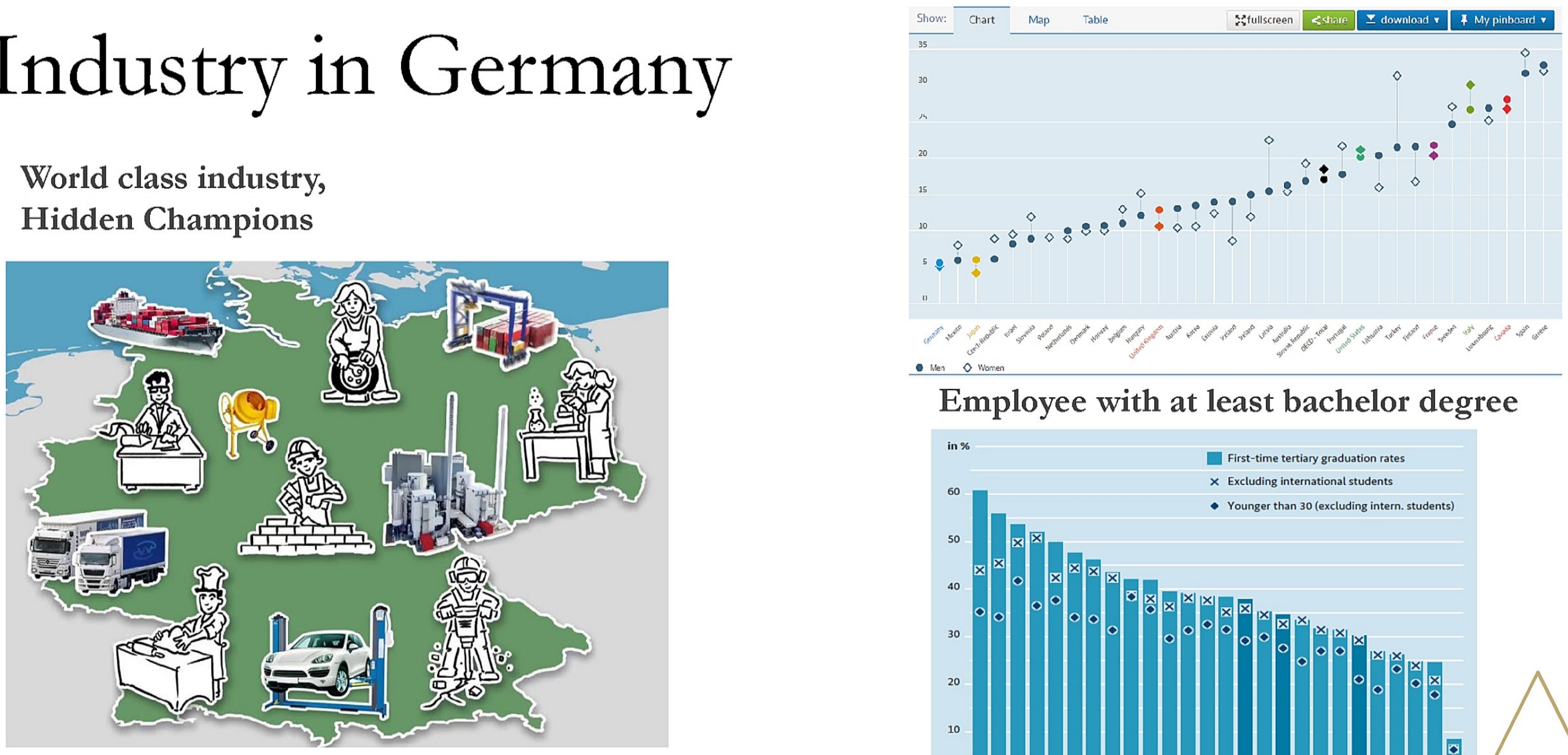

Employee with at least bachelor degree

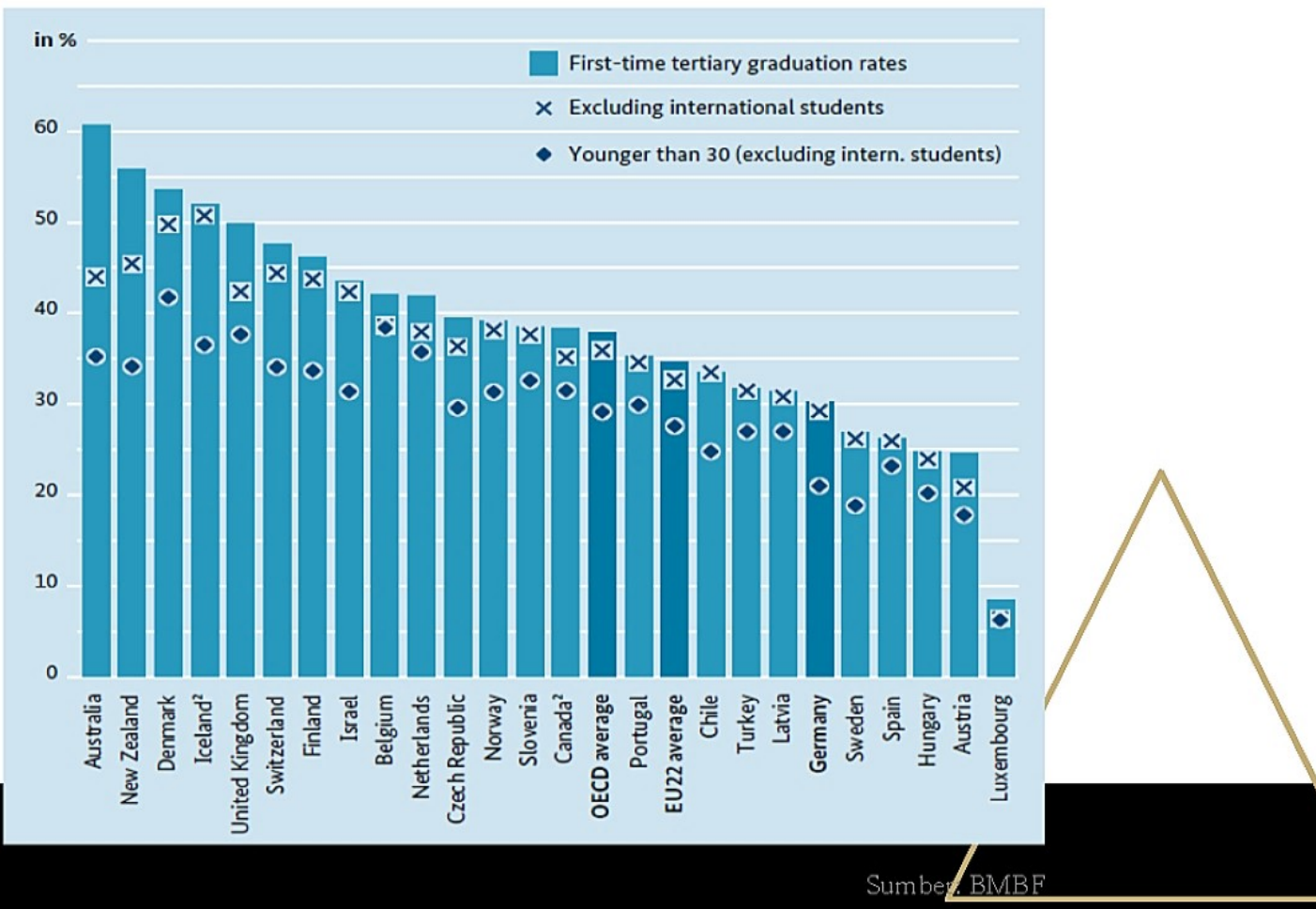




\section{Types of Higher Education in Germany}

University/Technical

University

University of

Applied Sciences (FH)

University of Cooperative Education (Dual System)

School of Education (PH)

Theologische Hochschule

Fachhochschulen für öffentliche

Verwaltung (FHöV) and

DHV Speyer
JACOBS

UNIVERSITY

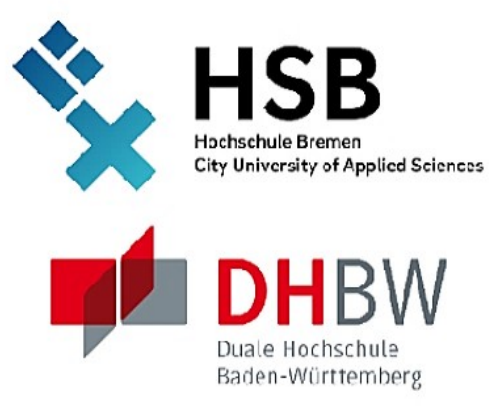

Pädagogische Hochschule
HE I DELBERG

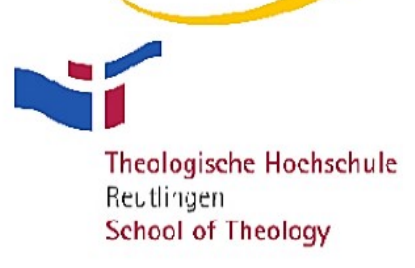

HFä
$\mathbb{V} \mathbf{V I T}$

Hochschule für Technik
und Wirtschaft Berlin

BA SACHSEN

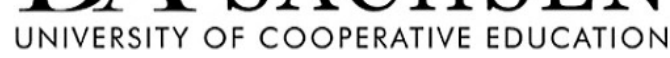

=1. Hessische Berufsakademie

phis

(七) $\begin{aligned} & \text { THEOLOGISCHE } \\ & \text { HOCHSCHULE } \\ & \text { ELSTAL }\end{aligned}$

Pädagogische Hochschule Freiburg Universite des Sciences de 'Education - University of Education

\section{fth ${ }^{\text {业 }}$ \\ Freie Theologische \\ Hochschule Gießen}

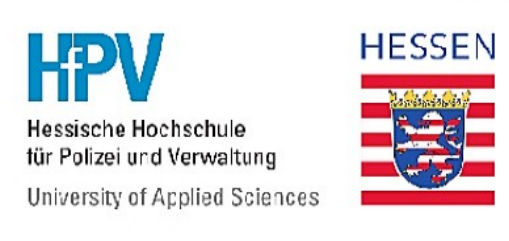




\section{Mentimeter Quiz}

Program studi apakah yang tidak ditawarkan

di University of Applied

Science/Fachhochschule/Politeknik di Jerman? 


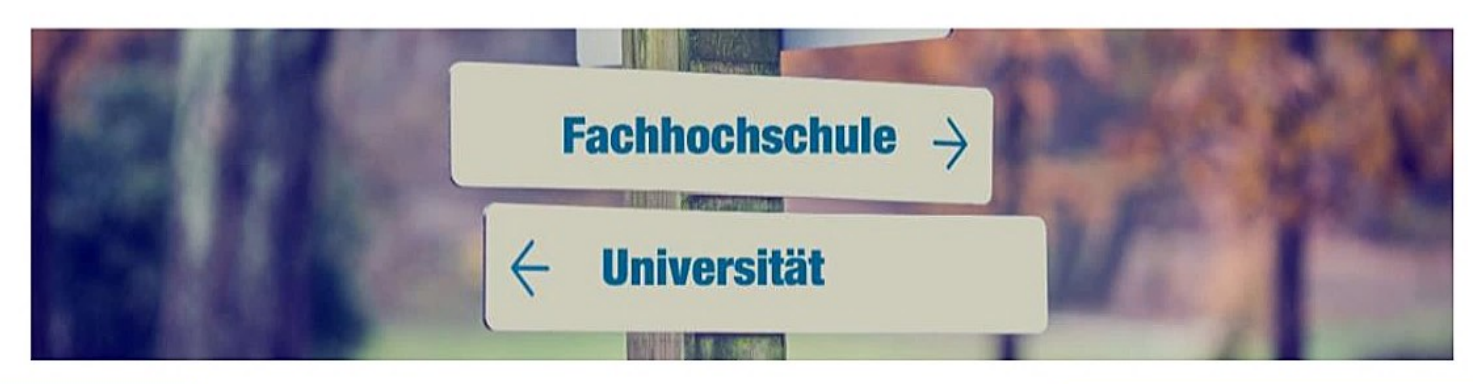

\section{University}

- Offer almost all study programs

- Offer PhD programs

- Focuses on research, theories, and sciences

- Learning in large classes

- Minimum student supervision

- Professors have experiences in research
University of Applied Sciences

- Do not offer medicine, teacher education, law, and natural sciences

- No PhD programs, except in cooperation with universities

- Focuses on the applications of sciences

- Learning in smaller classes

- Intensive student supervision

- Professors have experiences in industry 


\section{Bidirectional Relationship between Industry and Higher Education}

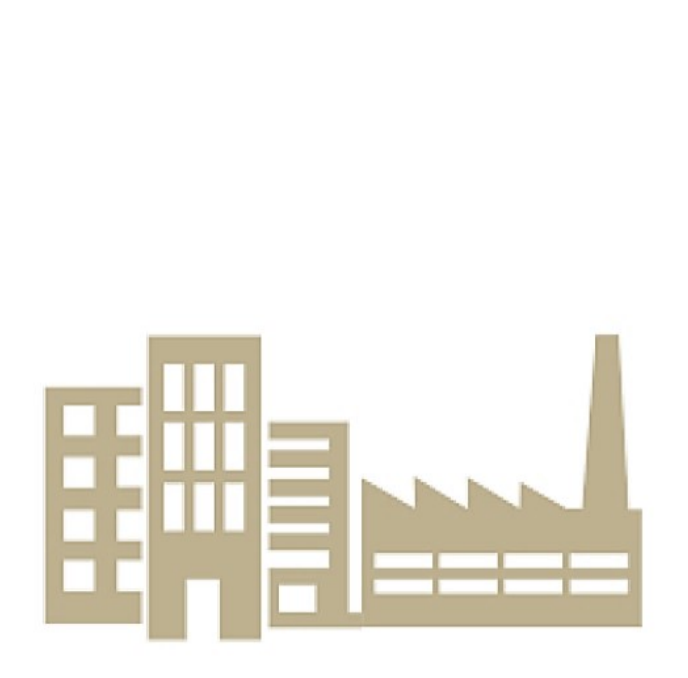

- Recruitment of professors

- Research contracts and funding

- Visiting lecturers

- Accreditation

- Internships

- Research transfer

- Consulting

- Supply of skilled labors

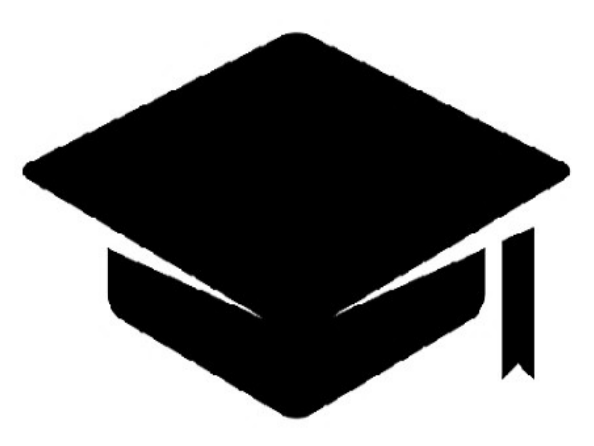




\section{Comparison between Indonesian and German}

\section{Lecturer}

\begin{tabular}{|l|l|l|}
\hline Qualification & S2 or S3 & $++\mathrm{S} 3++$ \\
\hline $\begin{array}{l}\text { Linearity vs. } \\
\text { transdisciplinary }\end{array}$ & Linearity is important & Transdisciplinary is strength \\
\hline $\begin{array}{l}\text { Decision maker in } \\
\text { recruitment }\end{array}$ & Policy makers & Users: colleagues, industry, students, ... \\
\hline Authority & $\begin{array}{l}\text { According to rules from } \\
\text { government/policy makers }\end{array}$ & Freedom of teaching and research \\
\hline Access to resources & $\begin{array}{l}\text { Resources are managed by „home } \\
\text { basec, e.g. study program, faculty } \\
\text { Teaching load }\end{array}$ & Resources are managed by the professor \\
\hline Performance evaluation & Standardized (nationally) & $9 / 10$ SWS (Uni), 18 SWS (FH/UAS) \\
\hline $\begin{array}{l}\text { Career mobility: industry - } \\
\text { academia }\end{array}$ & Generally not possible & $\begin{array}{l}\text { Based on agreement by considering strengths } \\
\text { and weaknesses }\end{array}$ \\
\hline RO WICAKSONO - OVERVIEW OF EDUCATION, RESEARCH, AND INNOVATIONIN GERMANY & Encouraged \\
\hline
\end{tabular}




\section{Typical Organization Structure in Universities}

Research strategy and implementation

Mittelbau

Main players in

research

\section{Professors}

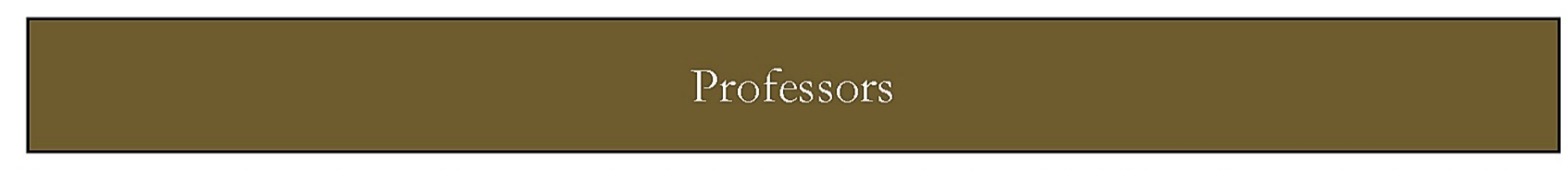

Senior post docs, junior group leaders, junior professors

Doctoral researchers

Post doctoral researchers

Students S1 and S2

Career path 


\section{Mentimeter Quiz}

Institusi pendidikan manakah yang tertua di Jerman? 


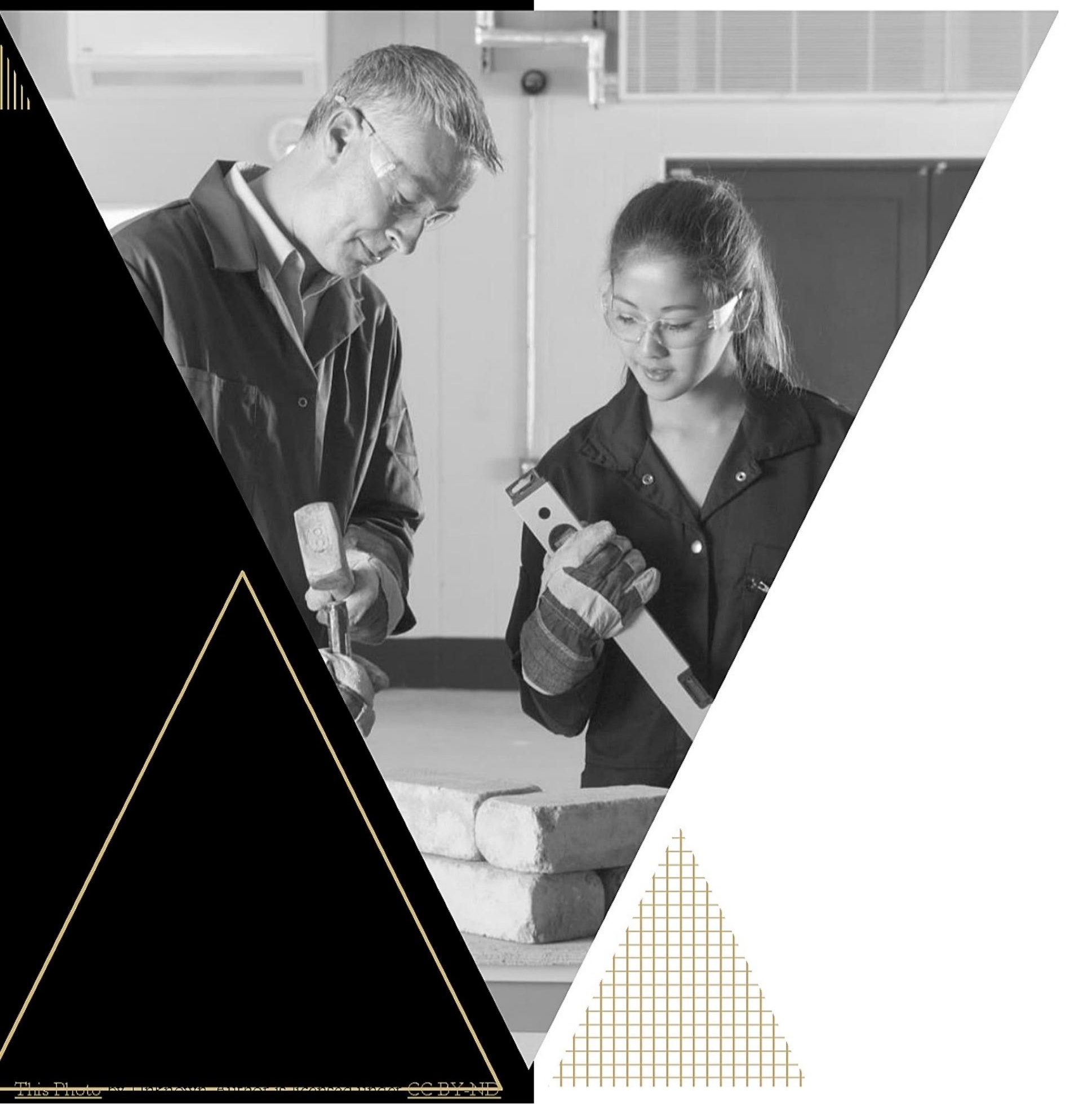

II.
Dual System Model

University of Cooperative Education and Vocational School 


\section{History of Vocational Education in Germany}

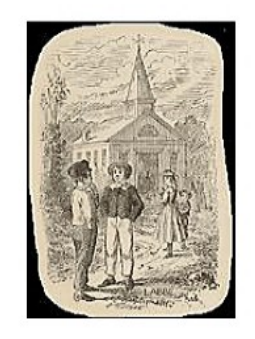

Sunday schools 16-18th century
Associations as quality control national system

1871

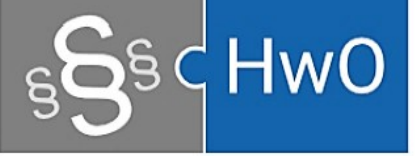

Handwerksordnung $(\mathrm{HwO})$ 1953

\section{BBiG}

Berufsbildungs gesetz

Berufsbildungsgesetz (BBiG) 1969

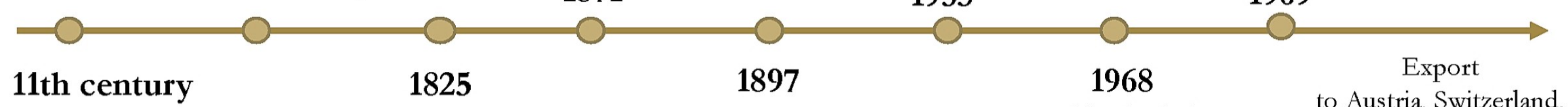

\section{1th century}

Interregional trades, standardization, government involvememt
Coordinated Sunday schools on state level

Handwerkskammern (chamber of commerce) as coodinator

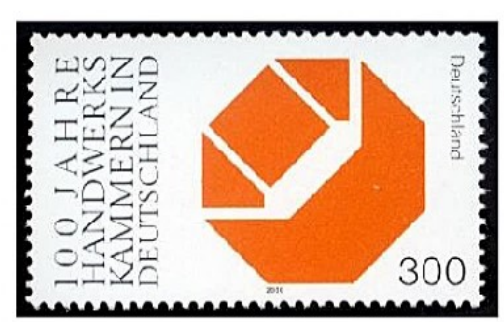

to Austria, Switzerland, Denmark
Fachhochschule

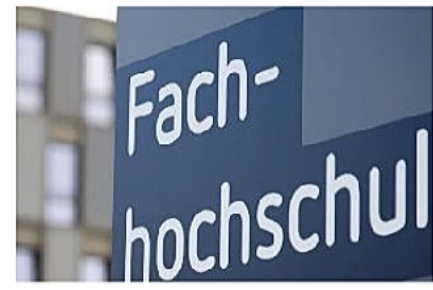




\section{What is Dual System?}

Business/Industry

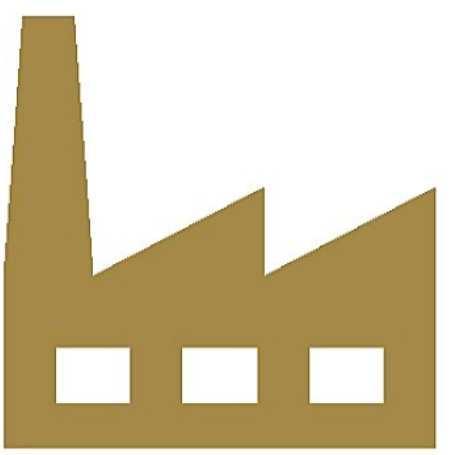

3-4 days a week

$( \pm 70 \%)$

- Students register to the company

- Students get working contract

\section{School/University}

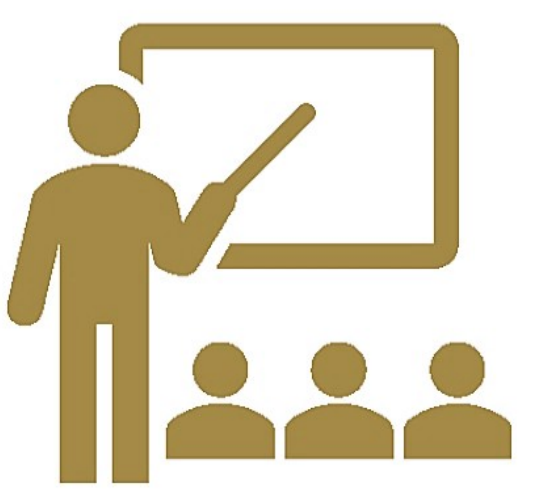

1-2 days a week

$$
( \pm 30 \%)
$$

- No maximum age limit 


\section{Education Structure/Focuses}

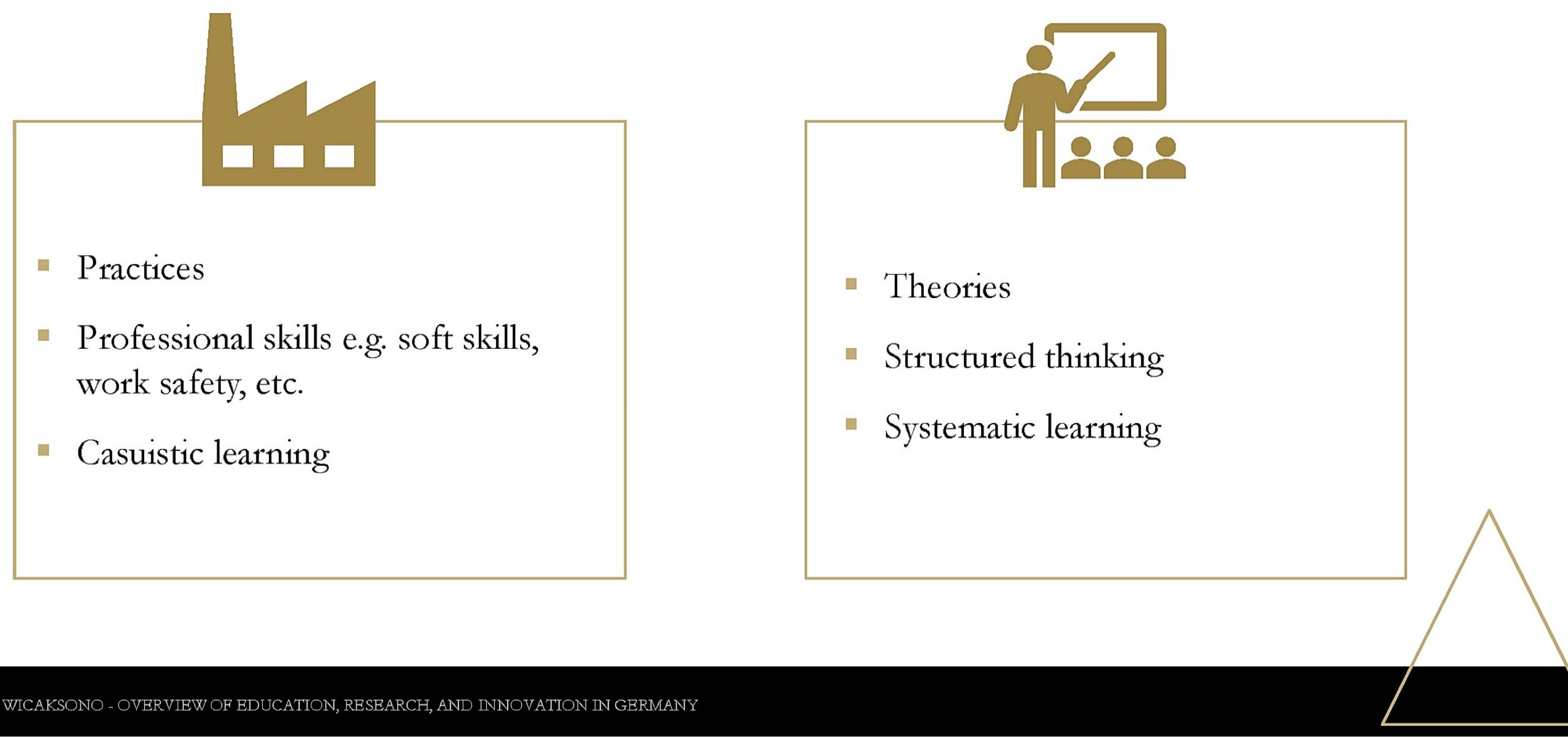




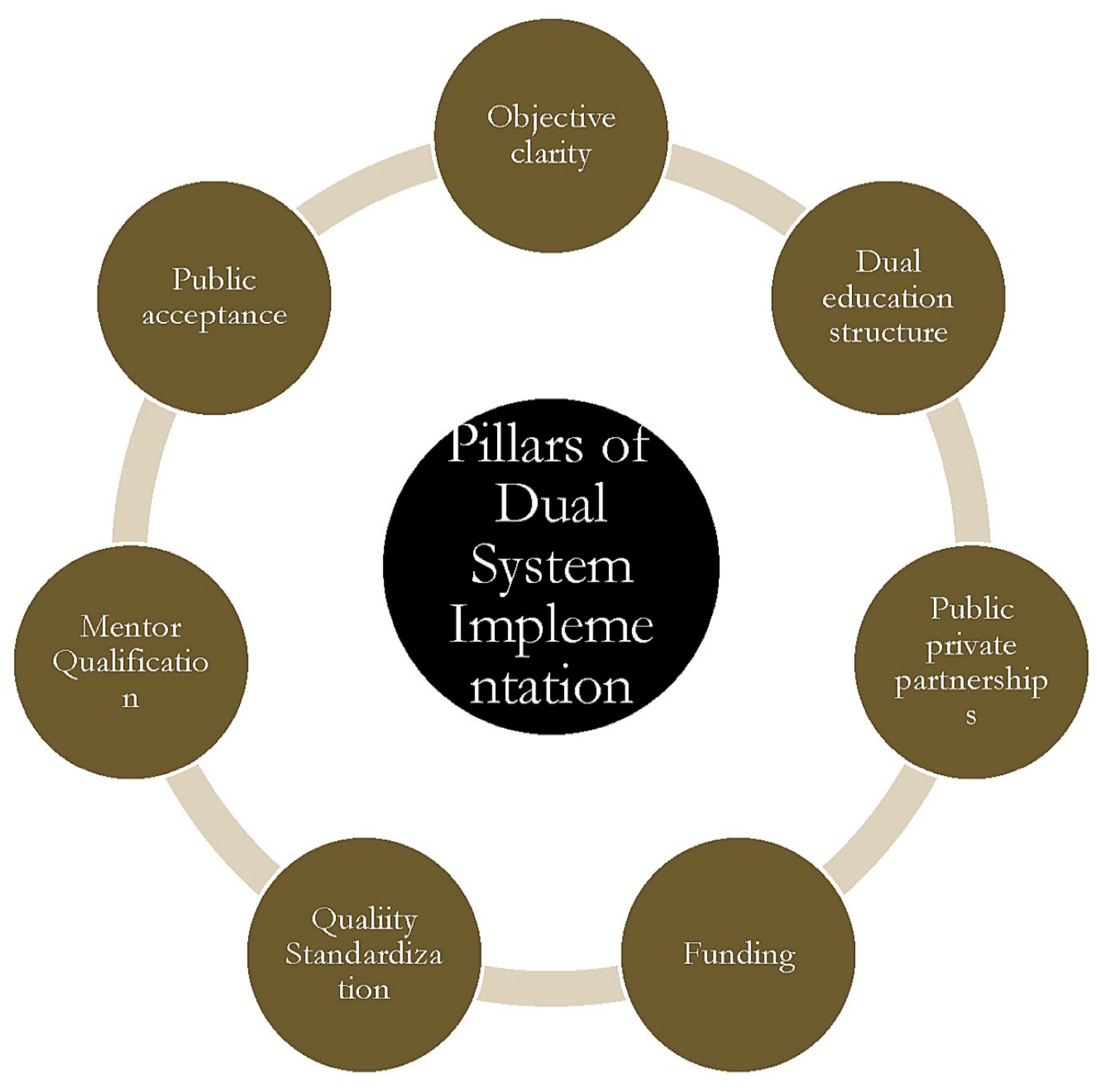




\section{Dual System is Public Private Partnership}

Regulation and supports:

- Responsible for school/university education

- Support negotiation processes
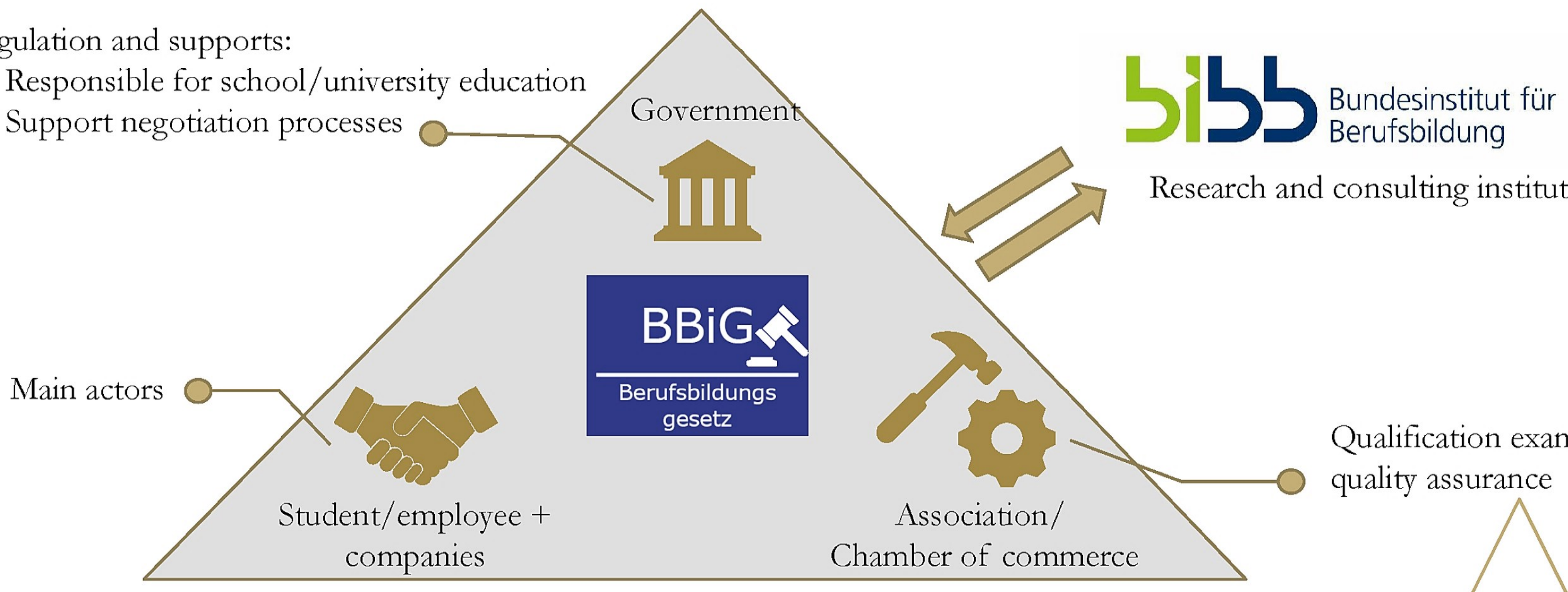

Qualification exam, quality assurance

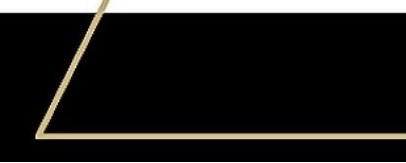




\section{Mentimeter Quiz}

Manakah negara yang kurang berhasil menerapkan pendidikan vokasi sistem dual ala Jerman? 


\section{Successful Countries Adapting Dual System}

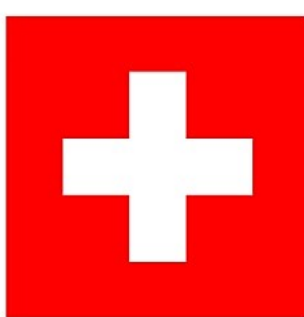

Switzerland

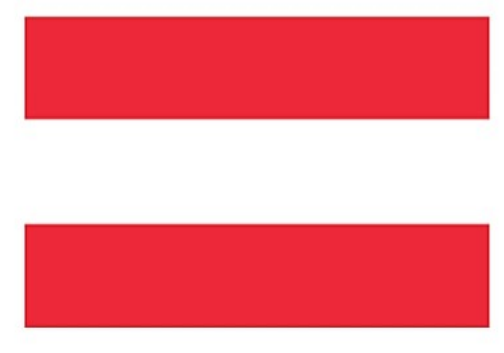

Austria

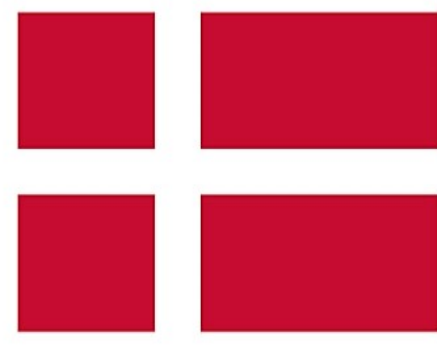

Denmark

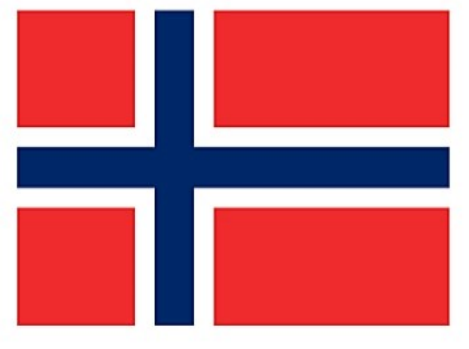

Norway

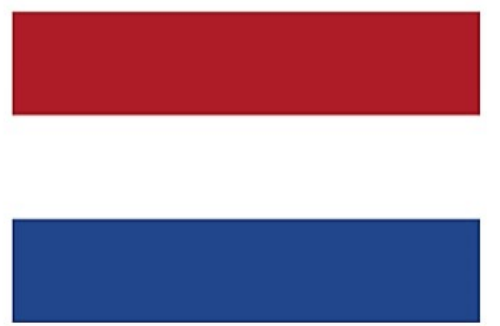

Netherlands

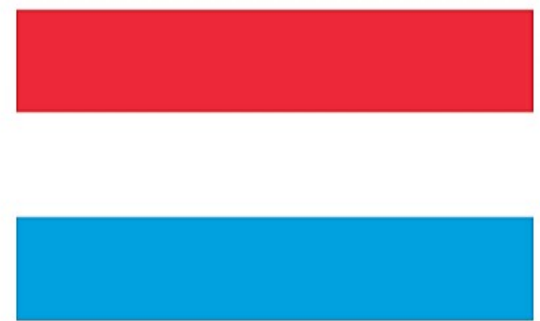

Luxemburg

Adapt each pillar to suit the local context 


\section{Not Successful Countries}

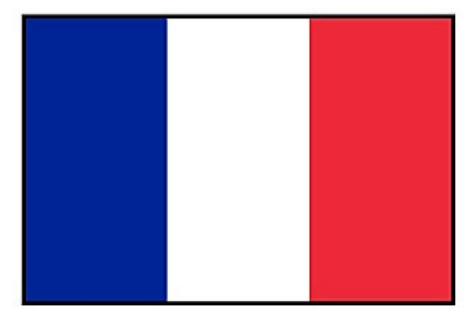

- Centralistic social structure

- Lack of a quality control role: professional associations and chambers of commerce

- There is no clear separation between planning and operational work

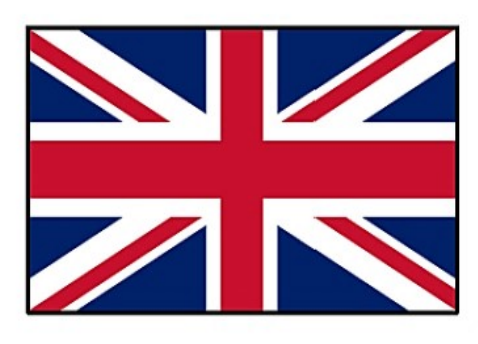

- The partnership between the government and the private sector is not successful

- Private sector is highly market dependent

- Vocational schools are either fully financed by the government or the private sector

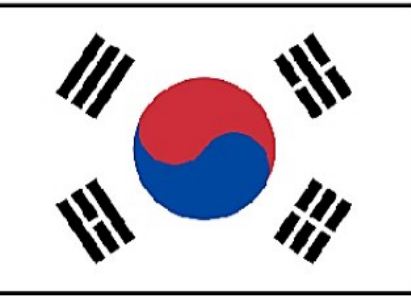

- Public acceptance of vocational graduates is low 


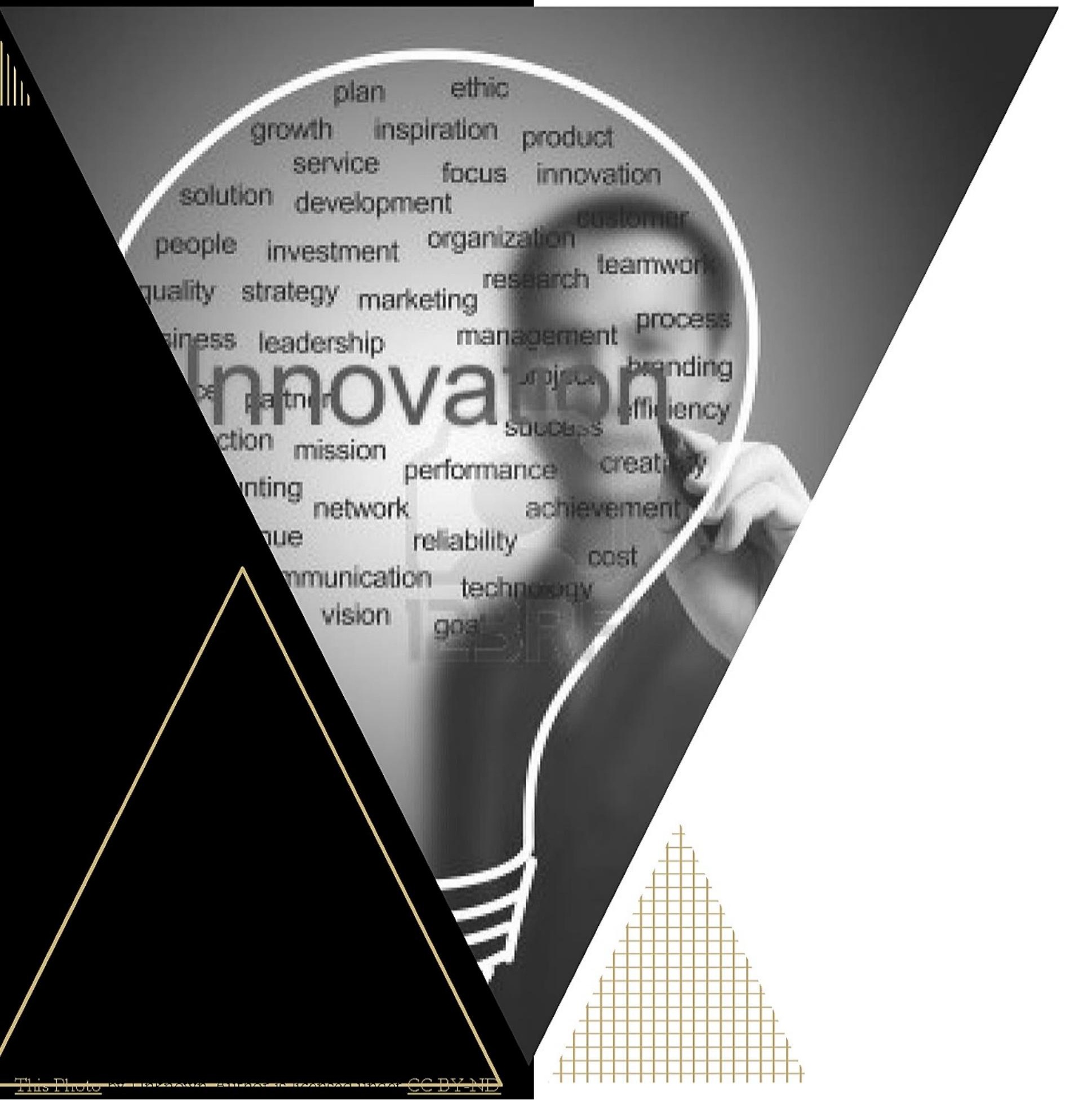

\section{III. \\ Triple Helix Innovation}

Research and Innovation in Germany 


\section{Mentimeter Quiz}

Manakah institusi riset Jerman yang

berfokus pada riset terapan? 


\section{Research in Germany}

\section{GERMAN R\&D UNDER THE MICROSCOPE}

A self-ranked assessment of how public and private research organizations in Germany are funded and their research priorities.

\section{RESEARCHER RANKINGS}

Germany has the highest number of researchers working in science

and technology industries and academia in the European Union.

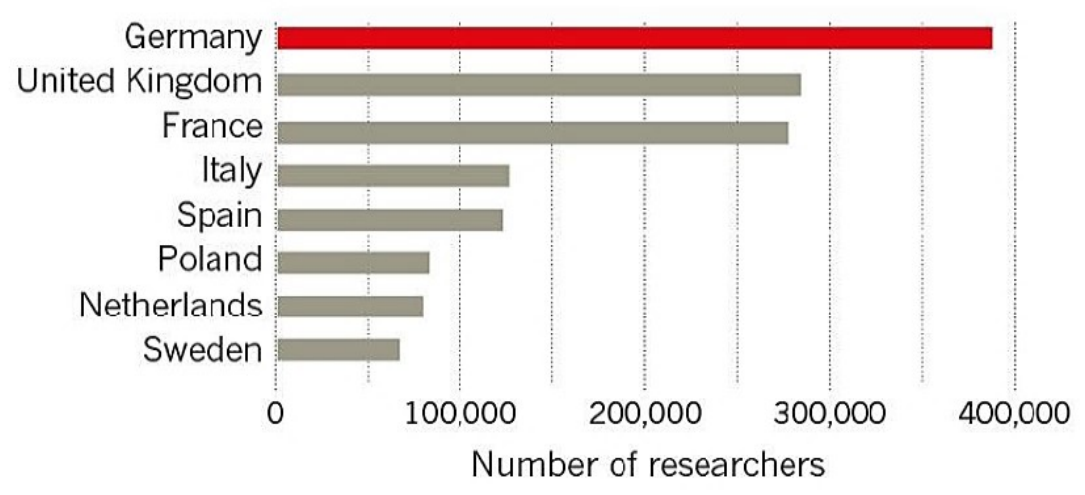

\section{THE GERMAN GOVERNMENT LOVES SCIENCE}

In 2016, researchers working across the natural sciences received more funding than those in other academic disciplines.

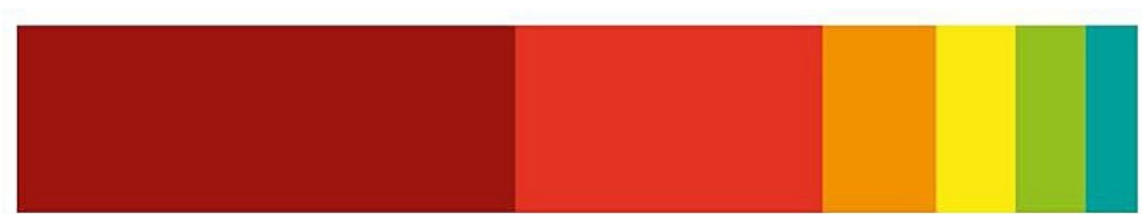

- Natural sciences $€ 5.7$ billion

Engineering \& technology $€ 3.5$ billion

Medical \& health sciences $€ 1.3$ billion

Humanities $€ 0.9$ billion

Social sciences $€ 0.8$ billion

$\square$ Agricultural sciences $€ 0.6$ billion

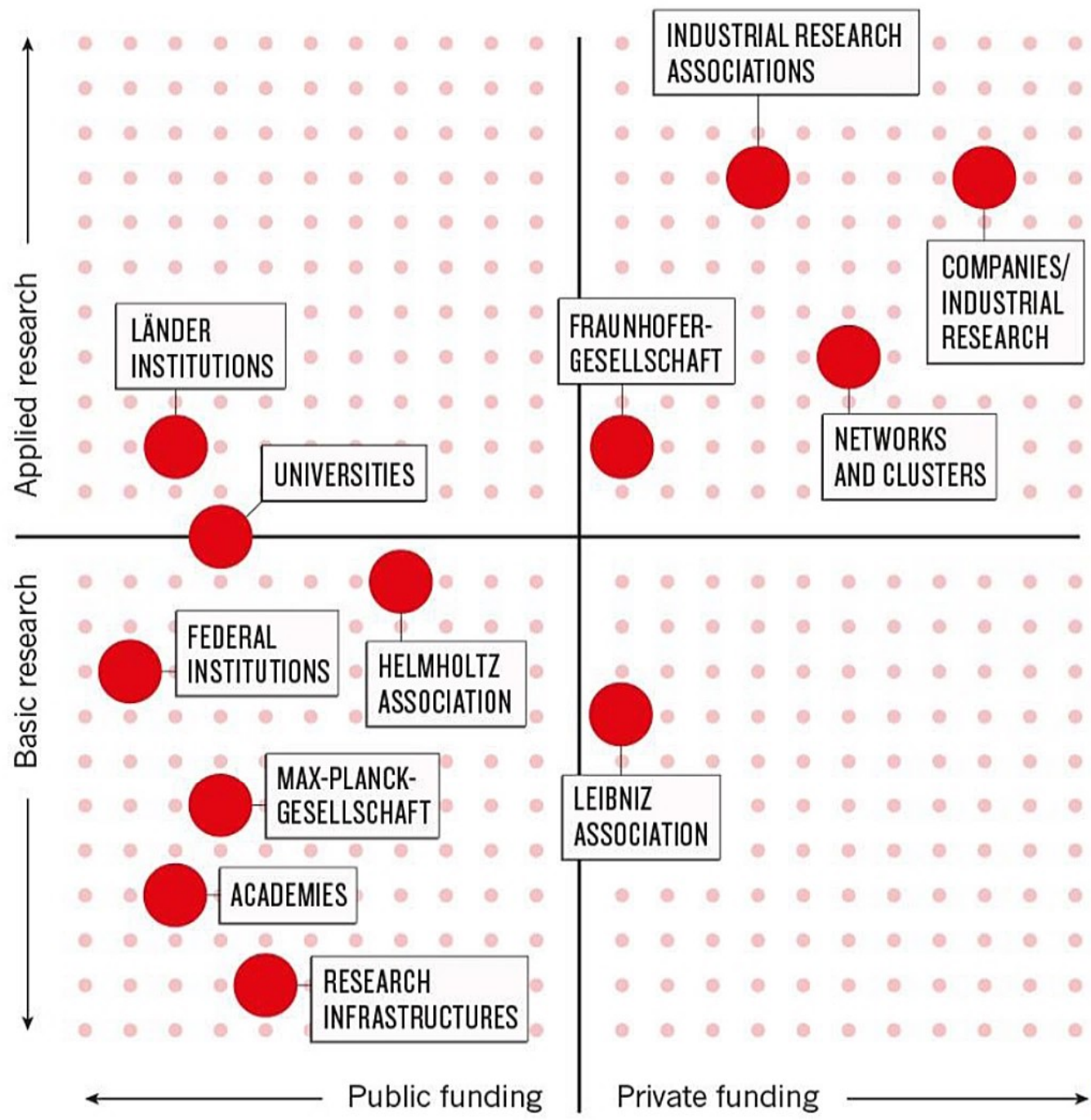

(Boytchev 2019) 


\section{Triple Helix Innovation Model}

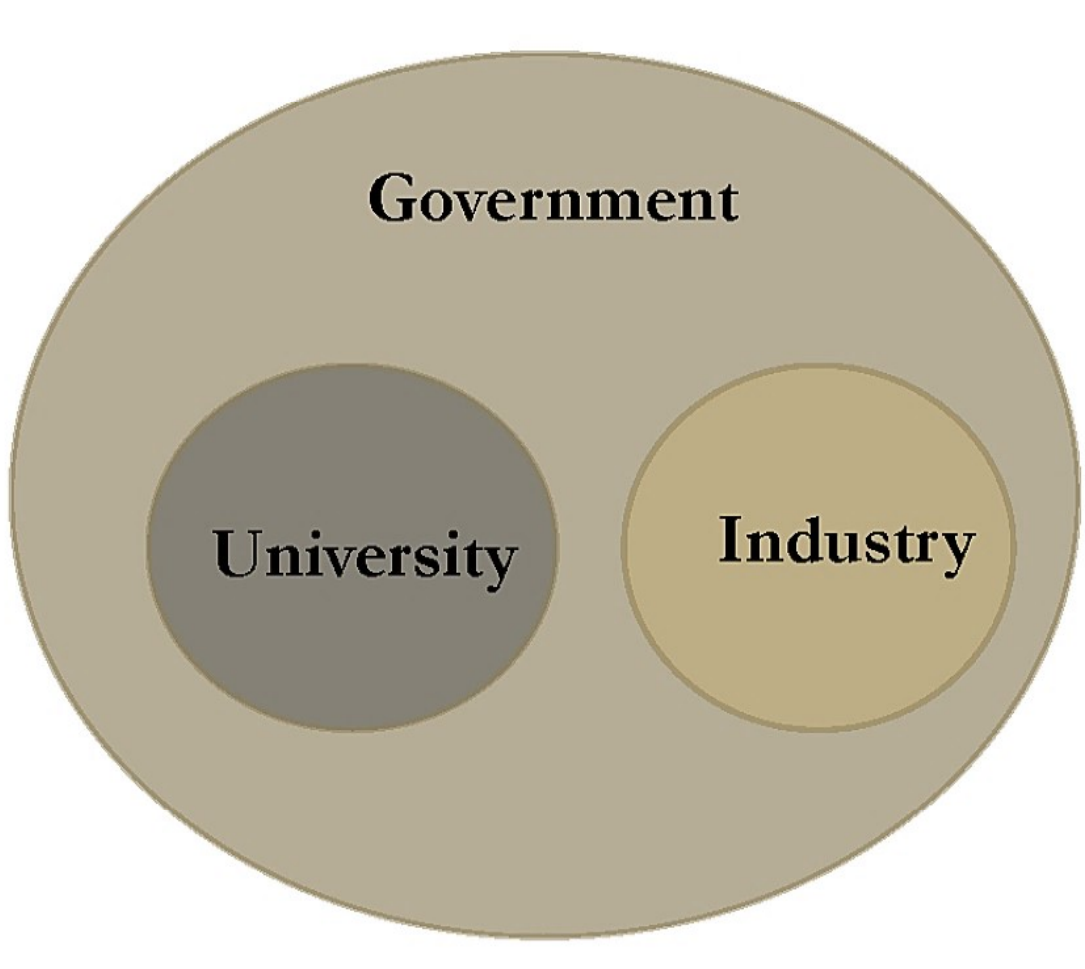

Model 1

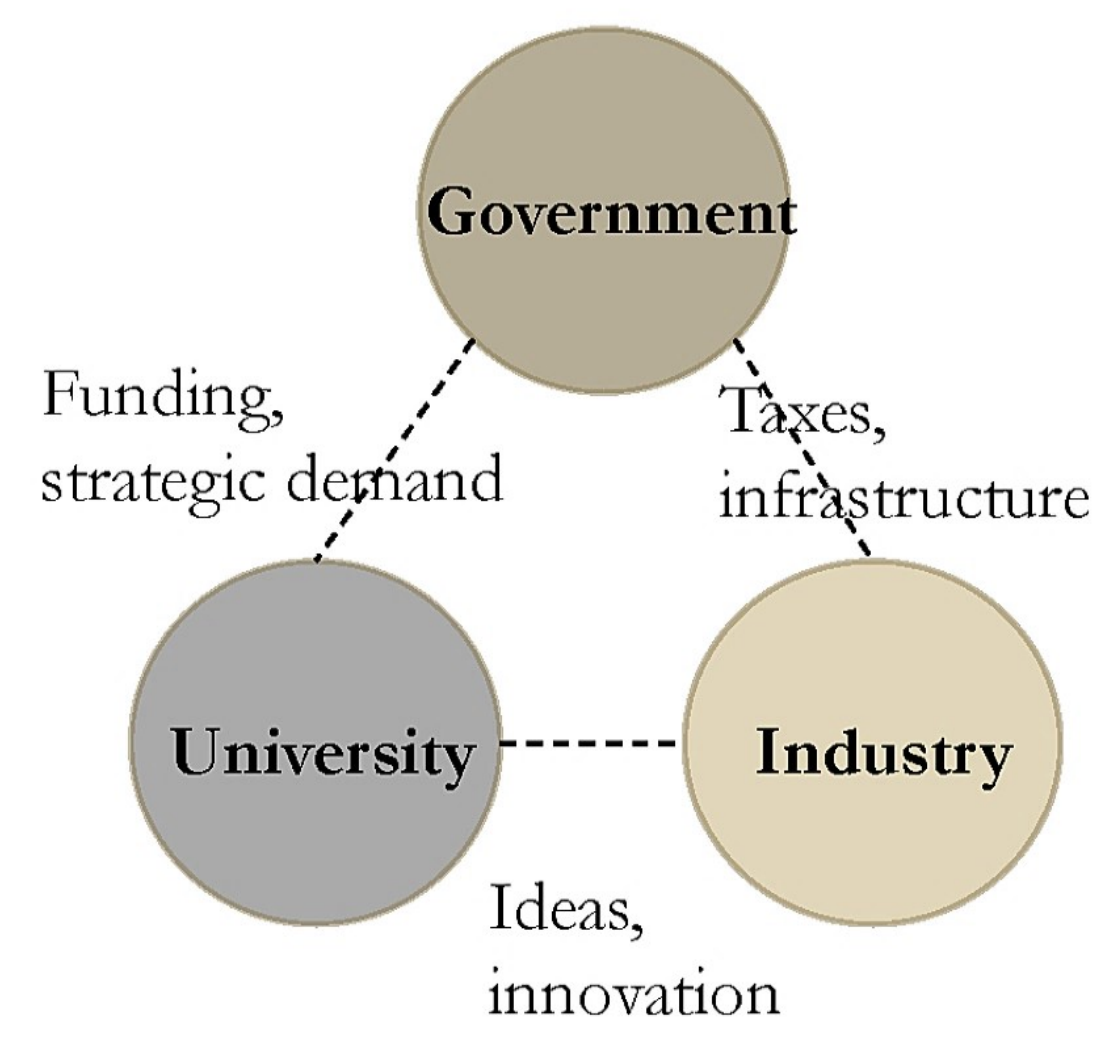

Model 2

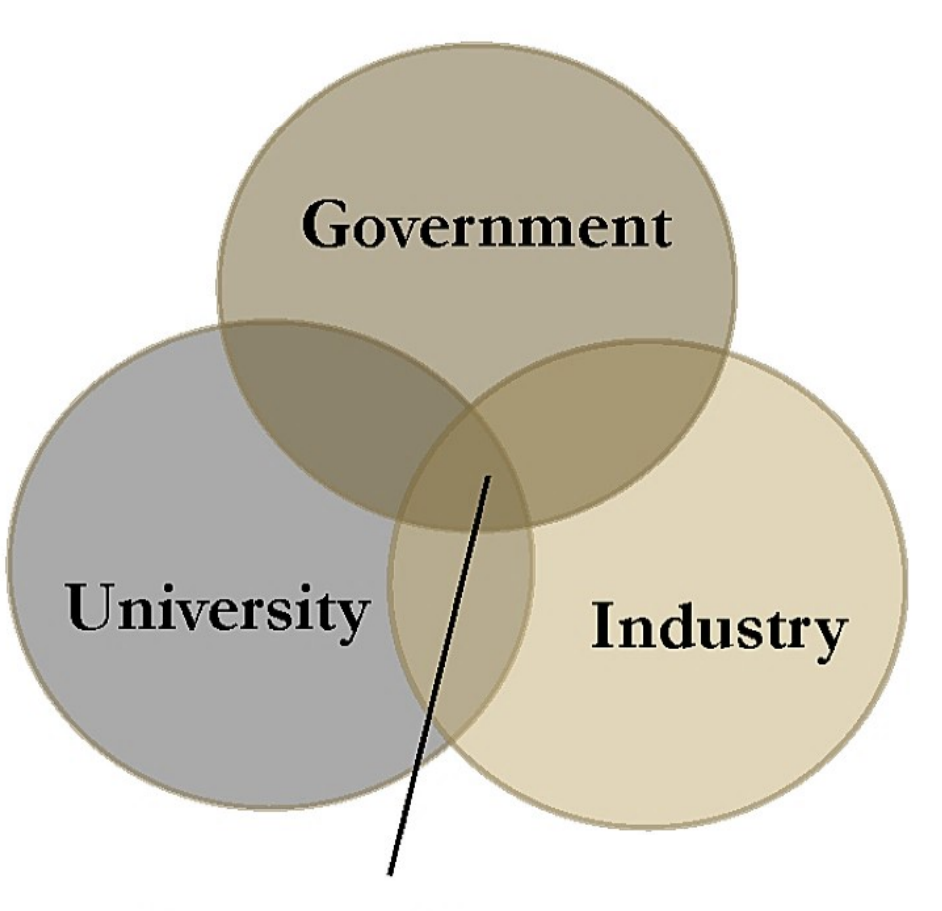

Integrated innovaton environment

Model 3 


\section{Triple Helix Implementation in Germany}

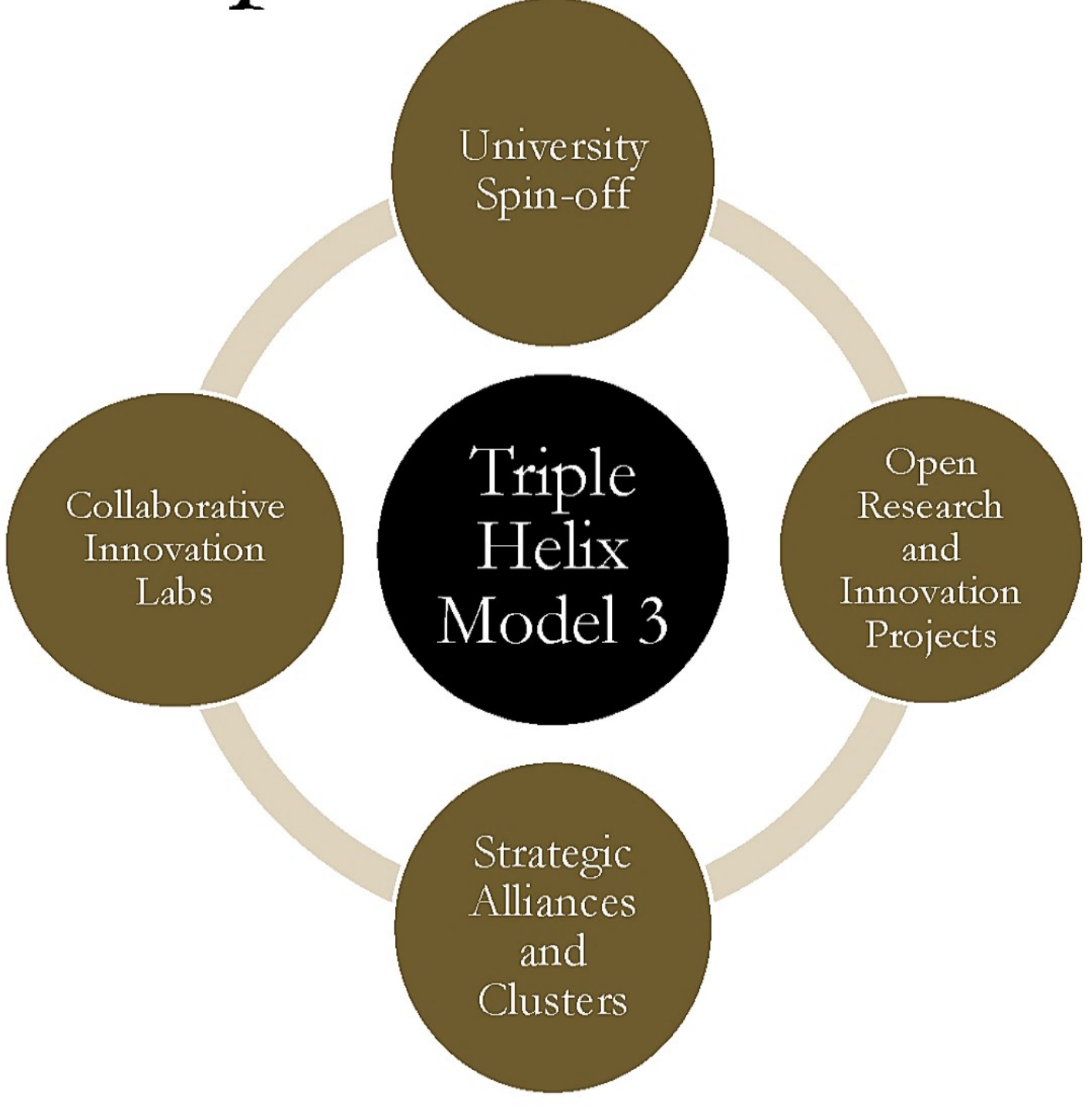




\section{1: University Spin-Off}

拸 | Bündesministerium

für Wirtschaft
und Technologie

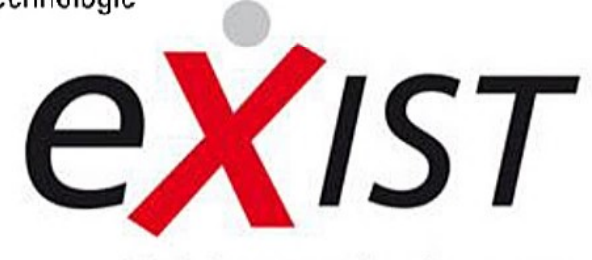

Existenzgründungen aus der Wissenschaft

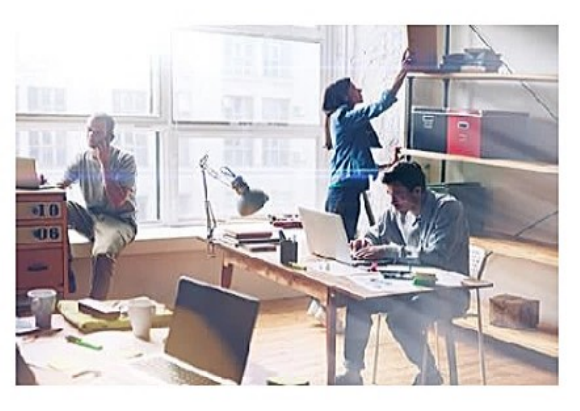

Grants for transfer from research to start-up

Support of start-up culture in university

\section{Example of successful startups}

Q OPENEXPERIENCE

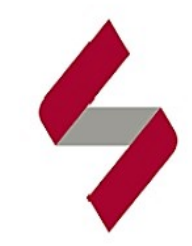

SHAREMAC

\section{Transformation of University Program}

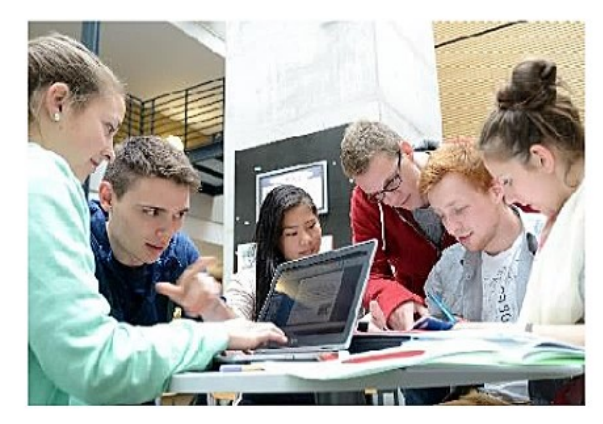

- Integration of startup programs in university's curricula

- Startup activities substitutes courses credits

Image: HS Karlsruhe

\% PHYSEC

security for things

\section{NosoEx}




\section{2: Open Research and}

\section{Innovation Projects}
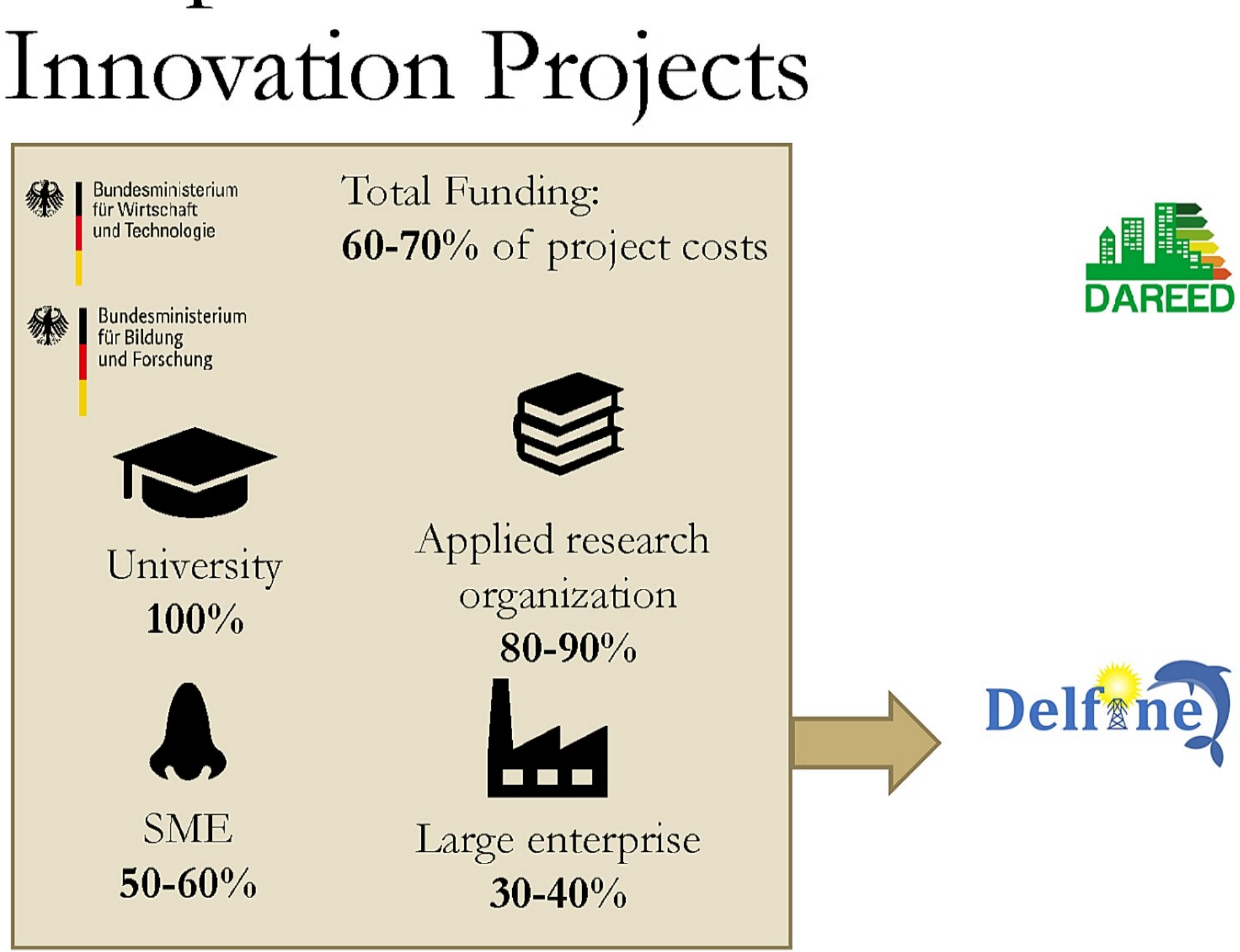

Project Examples

Delfane
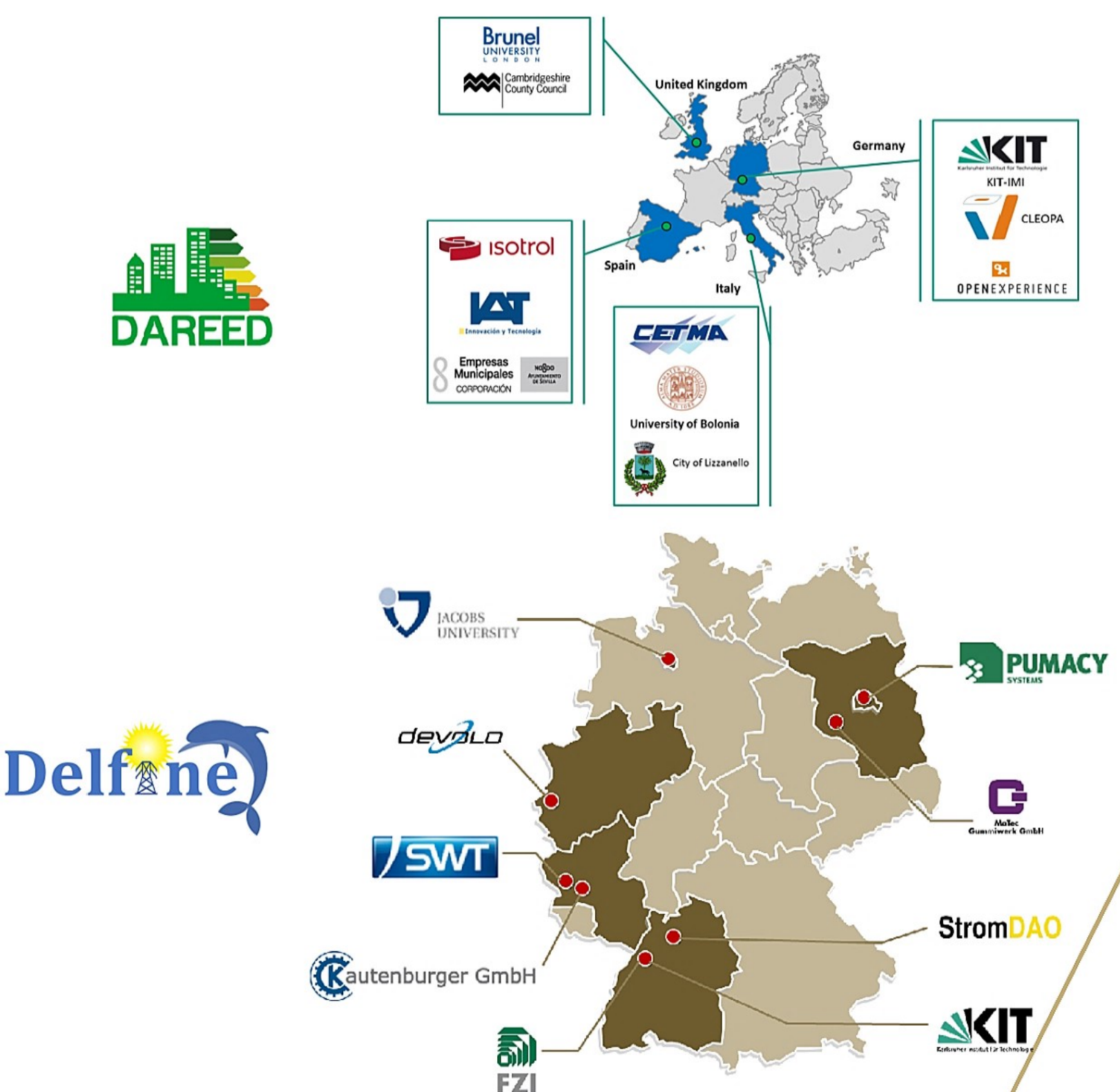


\section{Mentimeter Quiz}

Di kota manakah letak klaster inovasi software di Jerman? 


\section{3: Strategic Alliances and Innovation Clusters}

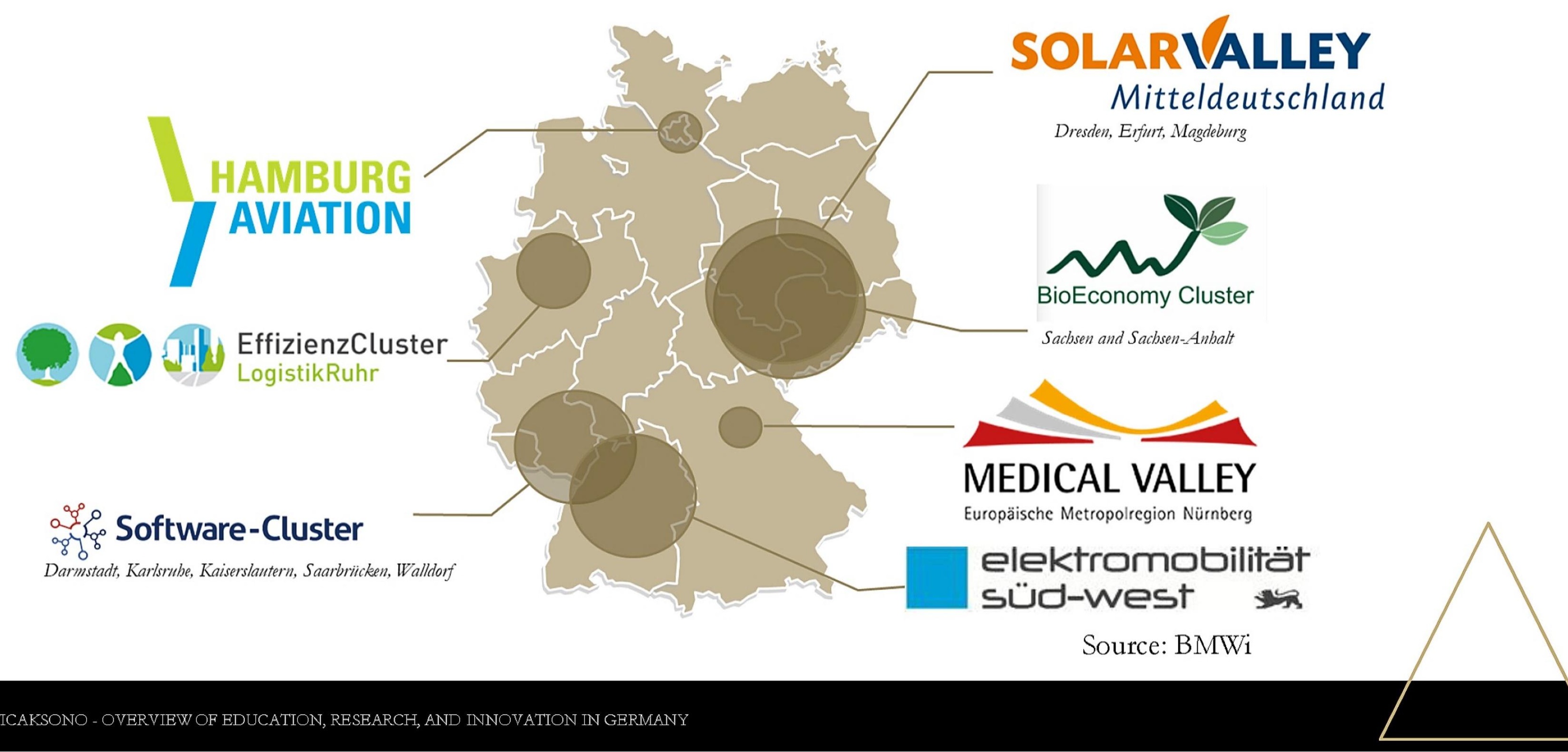




\section{4: Collaborative innovation labs: Industry 4.0 implementations}

Testbeds

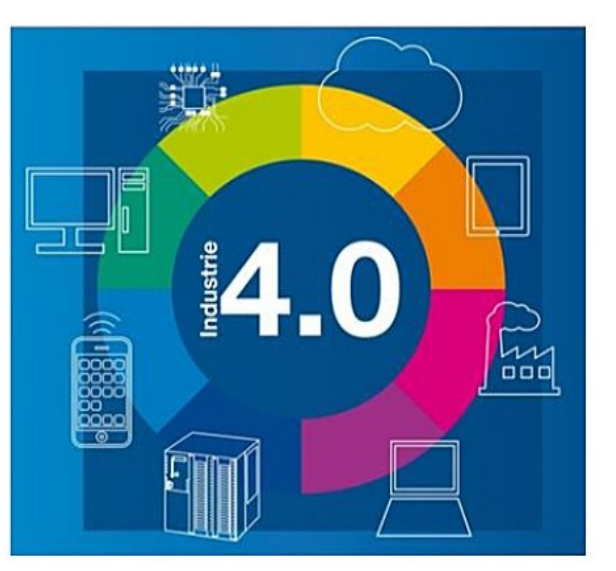

Small and Medium Enterprises

University Research

$\square$ Research Outside University

$\square$ Large Companies
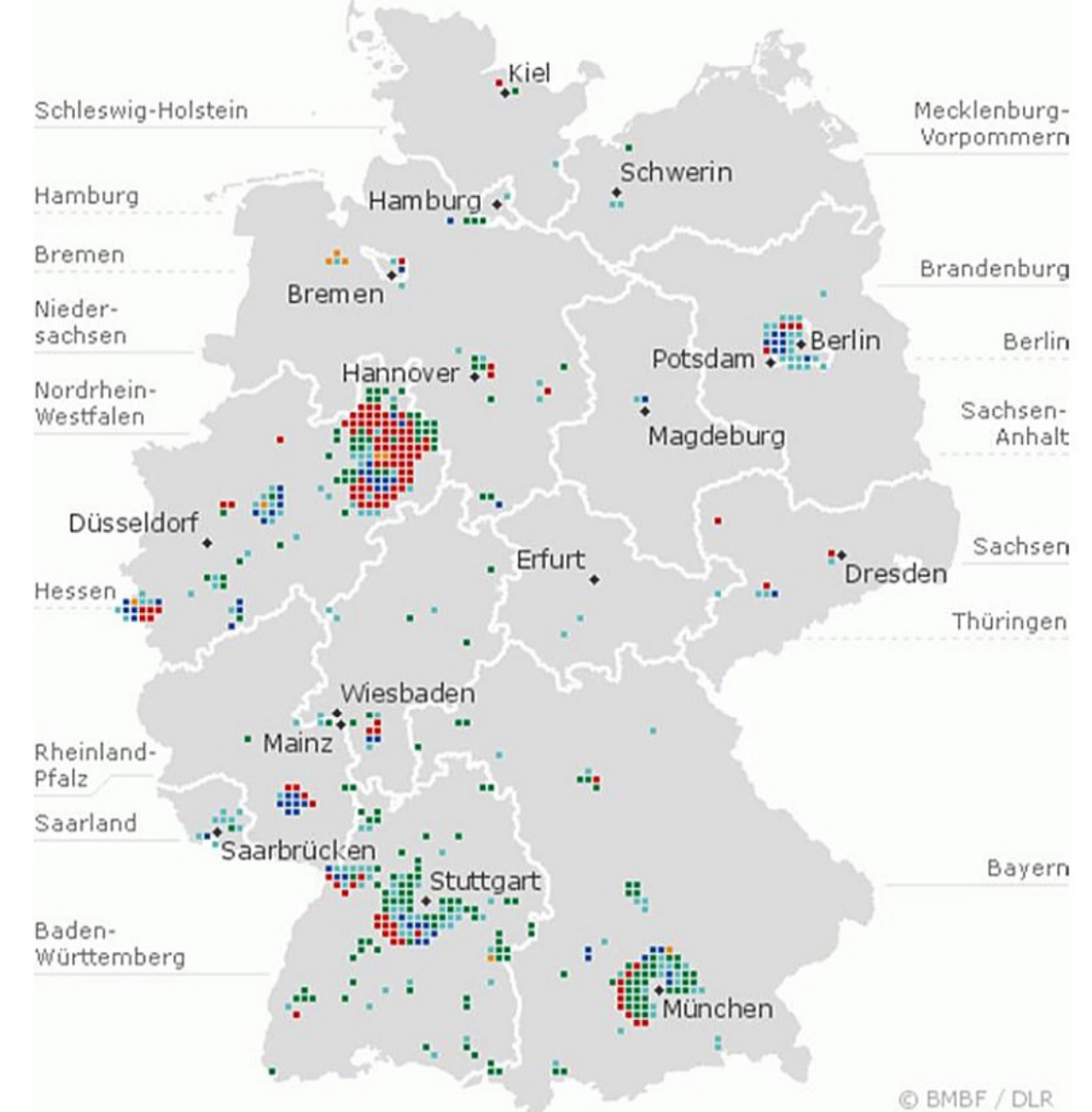

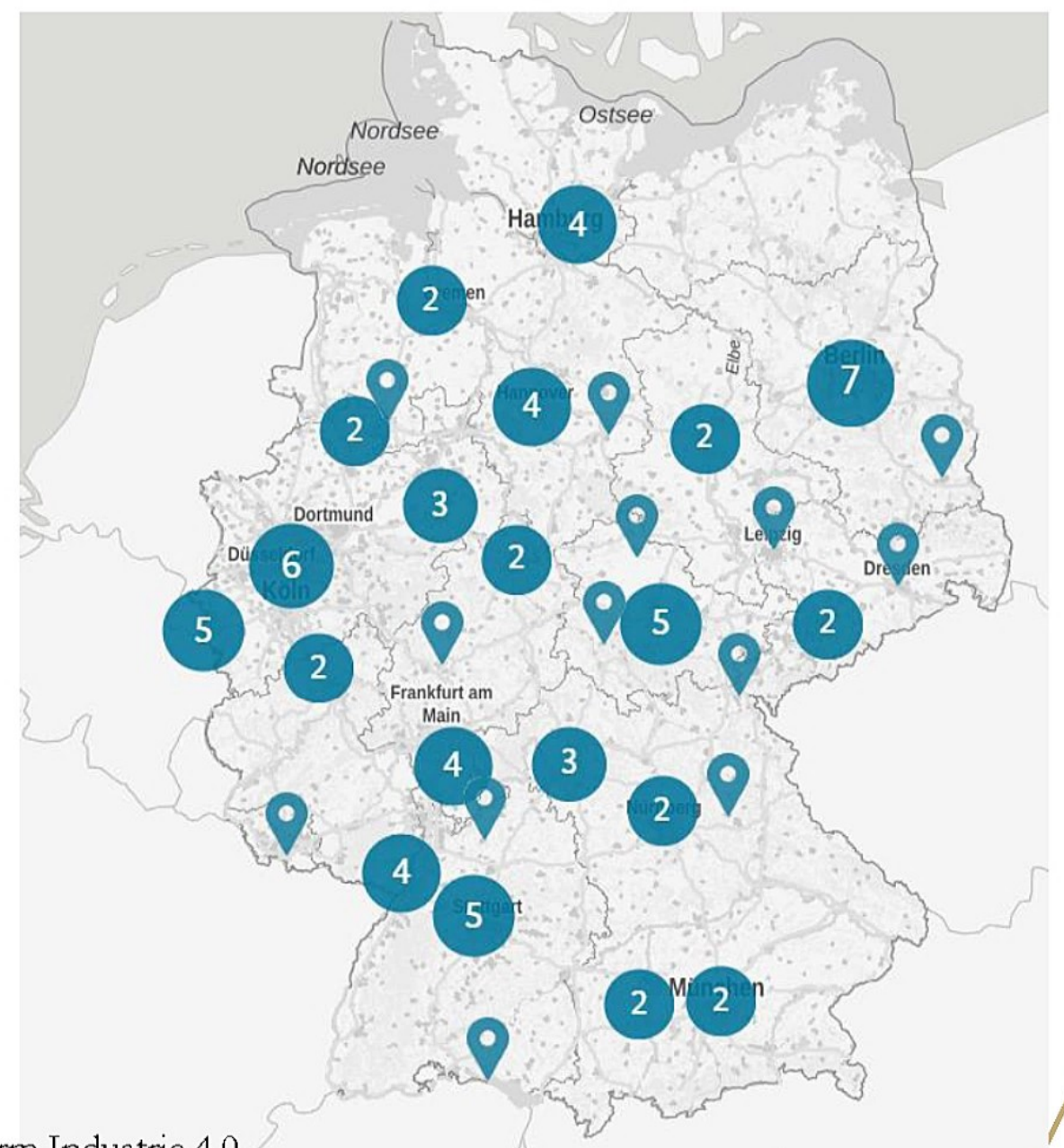




\section{Triple Helix Model 3 Requires Transformation of All Parties}

E

From teaching to research and innovation university

From closed to open innovation, from one-man show to ecosystem of global village

From top-down to bottom-up policy making 


\section{Indonesia: Quintuple Helix?}

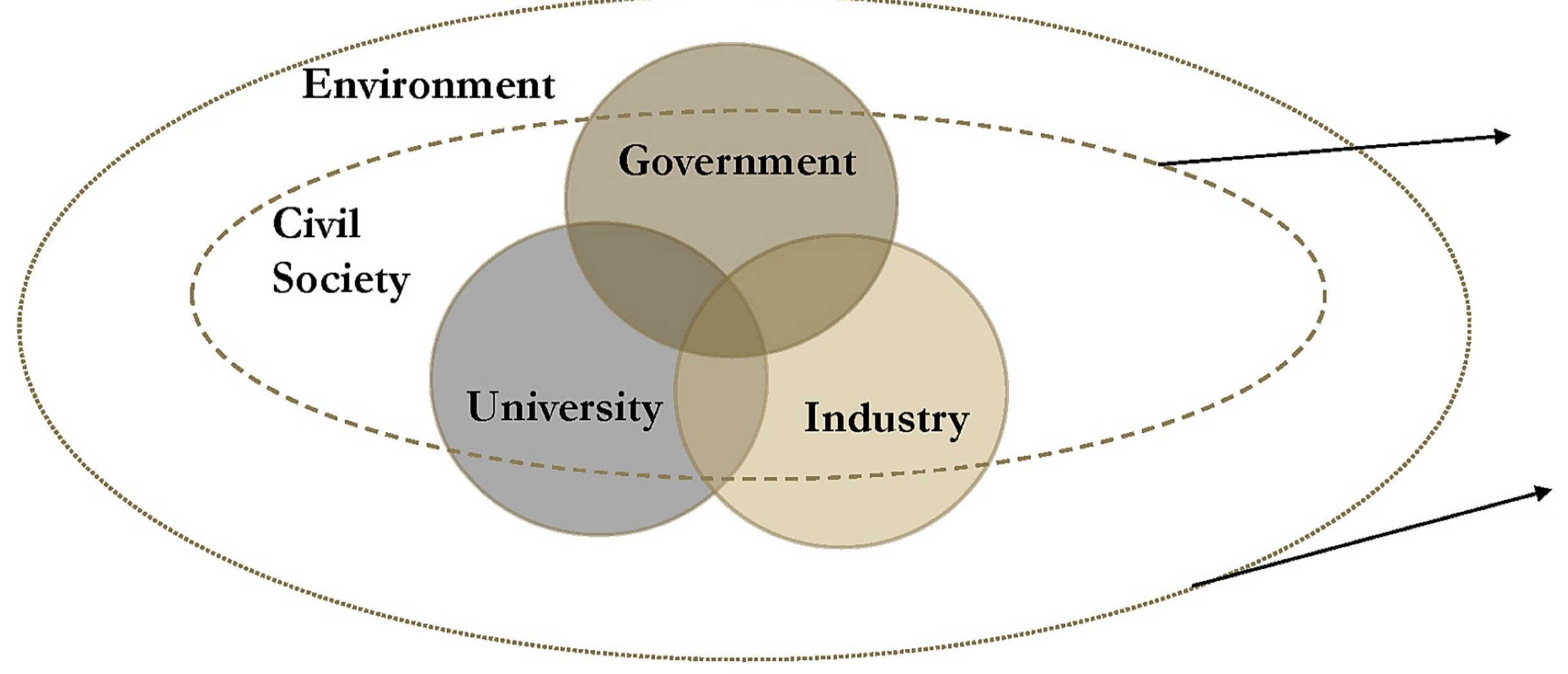

Collective society (Physical and virtual), "gotong royong"

Biodiversity,

Natural resources protection 


\section{Internationalization of Higher Education}

Contribution to

National Income

Getting skilled labour

Improving Academic Quality

Internationalization at IIome
- Low national budget allocation for higher education

- Government strategy is commercialization, autonomic implementation at univ. level

- Examples: UK, Australia, New Zaeland, US (partially), Canada (partially)

- Getting world's best talents

- Issuing work and residence permits after graduation

- Equality between local and foreign students

- Examples: Sweden, the Netherlands, Germany, Canada (partially)

- Scholarship to study abroad to learn best practices

- China: bidirectional, recruitment of researchers, world class research facilities

- Rusia: 100,000 scholarships to study abroad in applied sciences

- Outbound mobility: Brazil, Mexico, Kenya, Senegal, South Africa

- International competence improves local competence

- International class rooms and study programs

- Examples: the Netherlands, Jacobs University Bremen 


\section{Takeaways for Indonesia}

- Link and match required transformation in different sectors in higher education e.g. career mobility, reqruitments, curriculum, accreditation

- Adoption of dual system requires contextualization, not just copy-paste

- Balance between standardization and flexibility

- Triple Helix Model 3 requires transformation of all parties

- Internationalization has to base on local needs, not just pursuing the global ranking

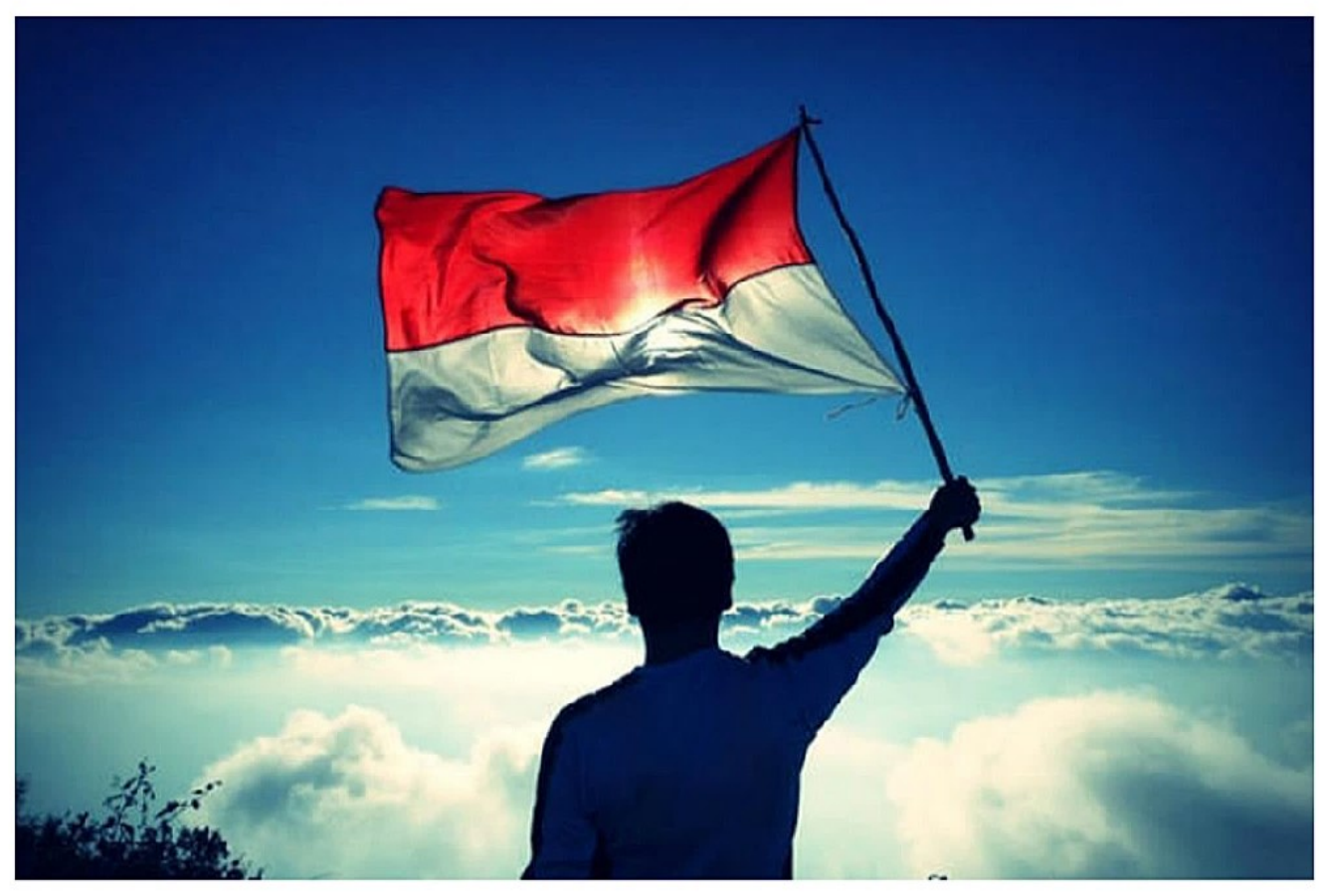

- Ranking is an indicator, the local impacts and needs are much more important 


\section{Thank You}

$\rightarrow \quad$ LinkedIn

https://www.linkedin.com/in/hendrowicakso no/

\section{Facebook}

https://www.facebook.com/hendro.wicakson o.9

\section{Email}

h.wicaksono@jacobs-university.de hendro.wicaksono@genolife.org

hendro.wicaksono@green-indonesia.com

\section{Homepage}

http://indeed.user.jacobs-university.de/ 